\title{
DENSITY AND DIVERSITY OF AQUATIC MITES IN A SPRING FED STREAM OF GARHWAL HIMALAYA, INDIA
}

\author{
Pankaj Bahuguna ${ }^{1}$, Shailza Negi ${ }^{2}$ and A. K. Dobriyal ${ }^{2}$ \\ ${ }^{1}$ Bio-diversity Lab, Department of Zoology, A.P.B.Govt.P.G.College Agustyamuni, District Rudraprayag, \\ Uttarakhand-246421, India. \\ ${ }^{2}$ Ecology Lab, Department of Zoology, B.G.R Campus Pauri, H.N.B.Garhwal University (A Central Univ.) Srinagar \\ Garhwal, Uttarakhand -246001, India.
}

Corresponding Author Email id: pankajpaurii@gmail.com

Received: 02.11.2019; Revised: 29.11.2019; Accepted: 11.12.2019

OSociety for Himalayan Action Research and Development

\begin{abstract}
Hydrachnidia, commonly called water mites are an important and diverse group of benthic insects which is usually neglected by the aquatic biologists in their routine biodiversity duties. Present study is an attempt to investigate the dynamics and diversity of water mites from a freshwater stream Randi Gad from Pauri Garhwal which is a lower order stream of river Alaknanda. Mites were collected using a square framed Surber Sampler of $1 \mathrm{~m}^{2}$ of the stream bed. Samples were preserved and brought to laboratory for further study. A total of fourteen species from five families were observed with a maximum density of 138 mites. $\mathrm{m}^{-2}$ in the month of January. Coefficient of similarity and Shannon wiener diversity index was calculated for diversity and cluster analytical study.
\end{abstract}

Keywords: Water mites, Randi Gad, Spring-fed Stream, Pauri Garhwal

\section{Introduction}

The water mites represent an important group of aquatic invertebrates which is almost neglected by the aquatic biologists. However, it is an important structural and functional unit of river systems. Mites of freshwater streams are often examined for seasonal cyclicity studies (Dutta and Malhotra, 1986), as biological indicators (Gerecke, and Schwoerbel, 1991; Smith and Vander, 1992), for molecular characterization (Otto and Wilson, 2001) and also for biodiversity assessment purposes (Cook, 1967,1974; Prashad, 1974). The knowledge regarding distribution of aquatic mites in river ecosystems of India is limited and highly fragmentary (Kumar and Dobriyal, 1992, 93; Kumar et.al., 2007; Pesic et.al., 2007, 2019a, 2019b). Aquatic mite fauna of India includes 275 species in 70 genera and 25 families (Pesic et. al., 2010). Kumar and
Dobriyal (1992) undertook some preliminary studies on the water mites of Garhwal Himalayas and described certain genera of lotic water species. After a long gap the research on aquatic mites restarted in the first decade of $21^{\text {th }}$ century (Kumar et al. 2006, 2007, Pesic et al. 2007a, b and Pesic et.al, 2019 a, b).The present study is an another significant attempt on density and diversity of water mites in a spring fed stream from Garhwal Himalaya.

\section{Material and Methods \\ Study Area}

Randi is an important third order spring fed stream (Latitude $-30^{\circ} 07^{\prime} 06^{\prime} \mathrm{N}$ and $78^{\circ} 35^{\prime} 21^{\prime \prime} \mathrm{E}$ ). It is an important tributary of Alaknanda River (Fig.1), which originates from the Ransi and Jhandidhar Peak in the Pauri Garhwal region. The flow regime is characterised by wide seasonal fluctuations, with peak flow during monsoon and the least during summer season. A $20 \mathrm{~km}$-long stretch of the stream just upstream from 
Alaknanda River was chosen as the study area. It has a stony substratum consisting of gravel, cobbles and a few boulders. The mean channel width is $7.0 \mathrm{~m}$ and the mean depth is $0.70 \mathrm{~m}$ during the study period (October 2017 to September 2018).

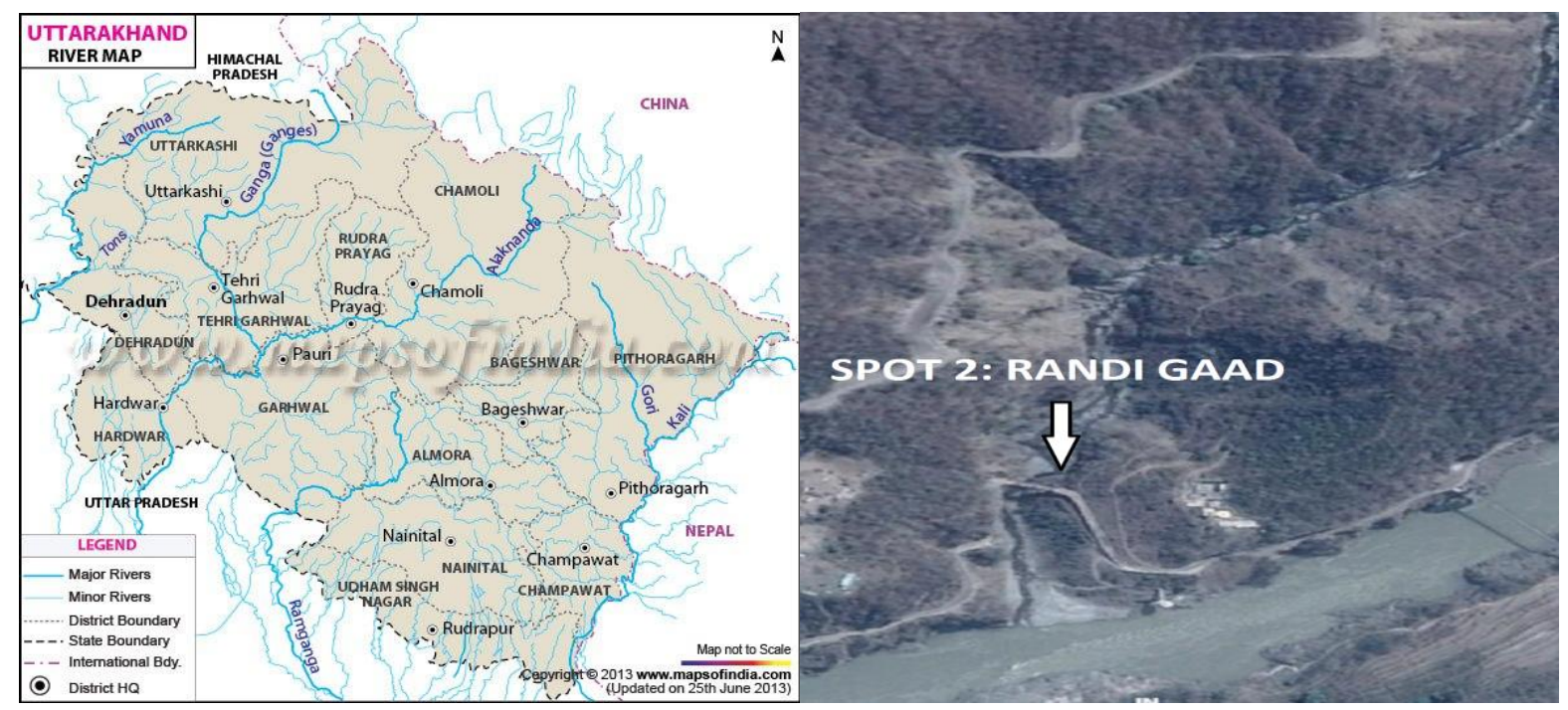

Fig 1: Location map of Pauri in Uttarakhand and view of Randi Gad stream

\section{Sampling Design and Analysis}

For density and diversity study of aquatic mites a square framed Surber Sampler was used that enabled the sampling of $1 \mathrm{~m}^{2}$ of the stream bed. The mite samples were collected from the stones very carefully. Species identification was done with the help of various keys provided by Cook (1967, 1974), Prasad (1974), Gerecke (2003), Kumar et.al. (2007), Pesic and Panesar (2008).

\section{Results and Discussion}

The monthly variations in the density and diversity of different aquatic mites (units. $\mathrm{m}^{-2}$ ) in the stream Randi gad during the year 2017-18 is presented in Table 1. A total of fourteen species from five families were observed. A maximum number of 138 mites. $\mathrm{m}^{-2}$ was recorded in the month of January and minimum density of 03 mites. $\mathrm{m}^{-2}$ was observed in the month of July 2018. The dominant species obtained in the river Randi gad were Torrenticola turkestanica, Monatractides oxystomus, Sperchon indicus,
Sperchon garhwaliensis, Atractides indicus, Atractides garhwali, Kongsbergia indica, Kongsbergia rucira and Feltria gereckei.

The Shannon-Wiener Index $\left(\mathrm{H}^{\prime}\right)$ for the aquatic mites communities of the stream Randi Gad during the year 2017-18 are shown in the Table 2 . The value of $\mathrm{H}^{\prime}$ was maximum 3.1450 in January and a minimum value of 2.7743 was observed in May. The similarity Index (S) between taxa of different months during are presented in the Table 3. The Index showed relatively higher values during favourable months (winter season) and lower during unfavorable months (monsoon season. 
Table 1: Density and diversity of aquatic mites in stream Randi Gad at $3^{\text {rd }}$ order stream.

\begin{tabular}{|c|c|c|c|c|c|c|c|c|c|c|c|c|c|}
\hline & Name of species & Oct & Nov & Dec & Jan & Feb & Mar & Apr & May & Jun & Jul & Aug & Sep \\
\hline $\mathbf{A}$ & \multicolumn{13}{|c|}{ Family - Torrenticolidae Piersig, 1902} \\
\hline & \multicolumn{13}{|l|}{ Genus - Torrenticola Piersig, 1902} \\
\hline 01 & Torrenticola uttarakhandensis & 02 & 04 & 06 & 07 & 03 & 01 & 00 & 01 & 04 & 00 & 01 & 00 \\
\hline 02 & Torrenticola chatterjeei & 00 & 02 & 04 & 05 & 00 & 02 & 00 & 01 & 00 & 00 & 00 & 01 \\
\hline 03 & Torrenticola turkestanica & 16 & 12 & 08 & 13 & 17 & 05 & 05 & 07 & 00 & 01 & 02 & 00 \\
\hline \multirow[t]{2}{*}{04} & Torrenticola wonchoeli & 00 & 00 & 02 & 05 & 00 & 00 & 02 & 00 & 02 & 00 & 00 & 00 \\
\hline & \multicolumn{13}{|c|}{ Genus - Monatractides K.Viets, 1926} \\
\hline \multirow[t]{2}{*}{05} & Monatractides oxystomus & 12 & 17 & 16 & 10 & 12 & 07 & 05 & 05 & 00 & 00 & 00 & 02 \\
\hline & Total & 30 & 35 & 36 & 40 & 32 & 15 & 12 & 14 & 06 & 01 & $\mathbf{0 2}$ & $\mathbf{0 3}$ \\
\hline \multirow[t]{2}{*}{$\mathbf{B}$} & \multicolumn{13}{|c|}{ Family - Sperchontidae Thor, 1900} \\
\hline & \multicolumn{13}{|c|}{ Genus - Sperchon Kramer, 1877} \\
\hline 06 & Sperchon indicus & 15 & 18 & 19 & 28 & 18 & 11 & 09 & 08 & 07 & 01 & 00 & 06 \\
\hline \multirow[t]{2}{*}{07} & Sperchon garhwaliensis & 14 & 09 & 09 & 19 & 14 & 05 & 05 & 00 & 04 & 00 & 01 & 02 \\
\hline & Total & 29 & 27 & 28 & 47 & 32 & 16 & 14 & 08 & 11 & 01 & 01 & 08 \\
\hline \multirow[t]{2}{*}{$\mathbf{C}$} & \multicolumn{13}{|c|}{ Family - Hygrobatidae Koch, 1842} \\
\hline & \multicolumn{13}{|l|}{ Genus - Atractides Koch, 1837} \\
\hline 08 & Atractides indicus & 09 & 10 & 08 & 14 & 15 & 05 & 05 & 07 & 00 & 00 & 02 & 00 \\
\hline 09 & Atractides garhwali & 07 & 05 & 10 & 05 & 00 & 01 & 00 & 05 & 03 & 00 & 01 & 03 \\
\hline 10 & Atractides yukii & 00 & 05 & 04 & 01 & 03 & 00 & 02 & 00 & 00 & 00 & 00 & 00 \\
\hline \multirow[t]{2}{*}{11} & Atractides incertus & 01 & 00 & 10 & 05 & 04 & 02 & 03 & 00 & 01 & 00 & 00 & 01 \\
\hline & Total & 17 & 20 & 32 & 25 & 22 & 08 & 10 & 12 & 04 & 00 & 03 & 04 \\
\hline \multirow[t]{2}{*}{$\mathbf{D}$} & \multicolumn{13}{|l|}{ Family - Aturidae Thor, 1900} \\
\hline & \multicolumn{13}{|l|}{ Genus - Kongsbergia Thor, 1899} \\
\hline 12 & Kongsbergia indica & 04 & 00 & 18 & 16 & 00 & 06 & 06 & 05 & 04 & 00 & 00 & 05 \\
\hline \multirow[t]{2}{*}{13} & Kongsbergia rucira & 00 & 09 & 10 & 10 & 04 & 00 & 04 & 08 & 05 & 00 & 03 & 00 \\
\hline & Total & 04 & 09 & 28 & 26 & 04 & 06 & 10 & 13 & 09 & 00 & 03 & 05 \\
\hline $\mathbf{E}$ & \multicolumn{13}{|l|}{ Family - Feltriidae K.Viets, 1926} \\
\hline & \multicolumn{13}{|l|}{ Genus - Feltria Koenike, 1892} \\
\hline 14 & Feltria gereckei & 00 & 11 & 12 & 00 & 08 & 08 & 05 & 00 & 04 & 01 & 00 & 03 \\
\hline & Total & $\mathbf{0 0}$ & \begin{tabular}{|l|}
11 \\
\end{tabular} & 12 & 00 & 08 & 08 & 05 & 00 & 04 & \begin{tabular}{|l|}
01 \\
\end{tabular} & 00 & $\mathbf{0 3}$ \\
\hline
\end{tabular}

Table 2: Shannon-Wiener diversity Index for aquatic mites at Randi Gad stream during 2017-18.

\begin{tabular}{|l|l|l|c|c|c|c|c|c|c|c|c|c|}
\hline Month & Oct & Nov & Dec & Jan & Feb & Mar & Apr & May & Jun & Jul & Aug & Sep \\
\hline $\mathrm{H}^{\prime}$ & 1.981 & 1.573 & 1.829 & 1.883 & 1675 & 1.782 & 1.635 & 1.666 & 1.399 & 0.732 & 1.401 & 1.509 \\
\hline
\end{tabular}


Table 3: Similarity index (S) between aquatic mites taxa of different months during the year 2017 2018 at the Randi gad stream.

\begin{tabular}{|c|c|c|c|c|c|c|c|c|c|c|c|c|}
\hline Month & Oct & Nov & Dec & Jan & Feb & Mar & Apr & May & Jun & Jul & Aug & Sep \\
\hline Oct & - & 0.800 & 0.869 & 0.818 & 0.736 & 0.900 & 0.700 & 0.777 & 0.667 & 0.333 & 0.667 & 0.706 \\
\hline Nov & - & - & 0.880 & 0.833 & 0.857 & 0.818 & 0.727 & 0.700 & 0.600 & 0.428 & 0.706 & 0.631 \\
\hline Dec & - & - & - & 0.963 & 0.833 & 0.880 & 0.880 & 0.956 & 0.696 & 0.353 & 0.600 & 0.727 \\
\hline Jan & - & - & - & - & 0.782 & 0.833 & 0.833 & 0.818 & 0.727 & 0.250 & 0.631 & 0.667 \\
\hline Feb & - & - & - & - & - & 0.761 & 0.857 & 0.631 & 0.631 & 0.461 & 0.555 & 0.625 \\
\hline Mar & - & - & - & - & - & - & 0.727 & 0.900 & 0.700 & 0.428 & 0.588 & 0.842 \\
\hline Apr & - & - & - & - & - & - & - & 0.600 & 0.700 & 0.428 & 0.470 & 0.421 \\
\hline May & - & - & - & - & - & - & - & - & 0.555 & 0.333 & 0.533 & 0.706 \\
\hline Jun & - & - & - & - & - & - & - & - & - & 0.333 & 0.533 & 0.706 \\
\hline Jul & - & - & - & - & - & - & - & - & - & - & 0.222 & 0.363 \\
\hline Aug & - & - & - & - & - & - & - & - & - & - & - & 0.286 \\
\hline Sep & - & - & - & - & - & - & - & - & - & - & - & - \\
\hline
\end{tabular}

\section{Acknowledgement}

First author (P.B.) gratefully acknowledge the financial assistance rendered by Science and Engineering Research Board (SERB) under a major Project No. ECR/2016/001291.

\section{References}

Cook, D.R. (1967). Water mites from India. Memoirs of the American Entomological Institute, 9: 1-411.

Cook, D.R. (1974). Water mite genera and subgenera. Memoirs of the American Entomological Institute, 21: 1-860.

Dutta, S.P.S. and Malhotra , Y.R. (1986). Seasonal variations in the macrozoobenthos fauna of Gadigarh stream (miran Sahib) Jammu. Indian J. Ecol. 13(1):136-145.

Gerecke, R. (2003). Water mites of the genus Atractides Koch, 1837 (Acari: Parasitengona: Hygrobatidae) in the western Palaearctic region: a revision. Zoological Journal of the Linnean Society, 138: 141-378.

Gerecke, R. and Schwoerbel, J. (1991). Water quality and water mites (acari, Actinedida) in upper Danube region, 1959-1984. Modern Acarology, 1: 483-491.

Hynes, H. B. N. (1970). The Ecology of running waters. Liverpool University Press 543 pp.

Kumar, N. (1991). Ecological studies on the macrozoobenthic communities of some hillstreams of the Alaknanda river system . D. Phil. Thesis submitted to H.N.B. Garhwal University Srinagar Garhwal.

Kumar, N. and Dobriyal, A. K. (1992). Some observations on the water mites of a Hillstream Khandagad in Garhwal Himalaya. Journal of Freshwater Biology 4: 193-197.

Kumar, N. and Dobriyal, A. K. (1993). Benthic diversity of Garhwal Himalayan hill streams in relation to their fishery potential. The third Indian fisheries forum proceedings, Pant Nagar. PP 159- 162.

Kumar, N., Kumar, K. and Pešić, V. (2007) Two new species of Sperchon Kramer (Acari: Hydrachnidia: Sperchontidae) from the Garhwal Himalayas (India). Systematic and Applied Acarology, 12, 31-36.

Kumar, N., Kumar, K., Kumar, S.and Pešić, V. (2006) Monatractides tuzovskyi sp. nov. (Acari: Torrenticolidae), a new water mite 
species from the Garhwal Himalayas (India). Acarina, 14 (2), 81-83.

Otto, J. C. and Wilson, K. J. (2001). Assesments of the usefulness of ribosomal $18 \mathrm{~s}$ and mitochondrial COI sequences in prostigmata phylogeny. Acarology: Proceeding of the 10th international congress. CSIRO publishing Melbourne.pp. 100-109.

Pesic, V. and Panesar, A. (2008). Studies on water mites (Acari: Hydrachnidia) from the Himalayas, I. The water mites genus Feltria Koenike, with description of eight new species. Zootaxa, 2119:1-22.

Pesic, V., Kumar, N. and Kumar, K. (2007a). Two new species of water mites of the family Hygrobatidae (Acari: Hydrachnidia) from the Garhwal Himalayas (India). Systematic and Applied Acarology 12: 161-166.

Pesic, V., Kumar, N. and Kumar, K. (2007b). A new species of Monatractides (Acari: Hydrachnidia: Torrenticolidae) and new records of other torrenticolid water mites from the Garhwal Himalayas (India). Systematic and Applied Acarology 12(3-4): 205-212.

Pesic, V., Smit, H. and Bahuguna, P. (2019a). New records of water mites (Acari: Hydrachnidia) from the Western Himalaya with the description of four new species. Systematic and Applied Acarology, 24(1): 5980.

Pesic, V., Smit, H. and Bahuguna, P. (2019b). New records of water mites (Acari: Hydrachnidia) from the Western Himalaya and description of three new species from Asia. Systematic and Applied Acarology 24(10): 1868-1880.

Pesic,, V., Chatterjee, T. and Bordoloi, S. (2010). A checklist of the water mites (Acari: Hydrachnidia) of India, with new records and description of one new species. Zootaxa 2617: $1-54$.

Prasad, V. (1974). A catalogue of mites of India. Indira Acarology Publishing House,
Ludhiana, :1-320.

Schwoerbel, J. (1986). Rheophilic water mites (acari) of Chile: 1 Hyporheic Species. Archiv Fur Hydrobiologie, Vol., 106:, 71-78.

Smith, H. and Hammen, H. Vander. (1992). Water mites as indicator of natural aquatic ecosystem of the coasted dunes of the Netherlands and north western France. Hydrobiologia, 231: 51-64.

$* * * * * * * * *$ 